\title{
Evaluation of the Effectiveness of Distance Learning in Dental Education During COVID-19 Pandemic in Turkey
}

\author{
Sibel Ezberci ${ }^{1}$, Bengisu Yildirim² ${ }^{-\infty}$ \\ ${ }^{1}$ Usak University Faculty of Dentistry Department of Pediatric Dentistry, Usak, Turkey. \\ ${ }^{2}$ Usak University Faculty of Dentistry Department of Prosthodontics, Usak, Turkey. \\ Correspondence Author: Bengisu Yildirim \\ E-mail: yildirim_bengisu@hotmail.com
}

Received: $14.04 .2021 \quad$ Accepted: 25.07 .2021

\begin{abstract}
Objective: COVID-19 pandemic affect dental education as well as everything. Online education become more popular in dentistry nowadays. It was aimed to evaluate the effectiveness of online lessons and satisfaction of the students about distance learning.

Methods: It was asked to respond a 42-items questionnaire at University of Uşak, School of Dentistry. Seven questions were aimed to gather information related to demographic data. Thirty-two lickert and three multiple choice questions to determine the quality of current non-clinical and clinical education and to form a guide for future online dental education. The questionnaire was filled out anonymously. The answers were analyzed on IBM SPSS Statistics for Windows, version 22.0 (IBM Corp, Armonk, NY, USA).

Results: This study aimed to reach 316 dental students, of which 302 (95.5\%) responded. The percent of female students was $57.6 \%$ and male students was $42.4 \%$. Male students more pleased than female students in term of distance learning $(p=0.032)$. Fourth grade students were significantly pleased distance learning than first and second grades students according to the satisfaction questions $(p<0.05)$. Most of the students agreed that they would prefer blended education (strongly agree, 43\%; agree, 22.2\%).

Conclusion: A certain satisfaction about online education was not obtained. Online clinical-based lessons were more difficult to understand for the students. Most of the students agreed that blended education is a good choice. It can be concluded that blended education will be a good alternative system for future dental education.
\end{abstract}

Keywords: Dental education, distance education, COVID-19

\section{INTRODUCTION}

The disease that appears firstly in Wuhan state, China lately 2019, is defined as (COronaVIrus Disease 2019, COVID-19) in January 2020 after the investigations on the patients who have respiratory system complains. While the virus isolated just from live animal selling seafood bazaar in Wuhan, it spread to other cities and countries by human-to-human transmission $(1,2)$. After worldwide transmission World Health Organization declared as 'pandemic' on 11 March 2020 (3).

Coronaviruses are the members of a crowded family that can cause diseases from flu to Middle East Respiratory Syndrome, (MERS) or Severe Acute Respiratory Syndrome, (SARS) (1). Severe Acute Respiratory Syndrome Coronavirus-2 (SARSCoV2) transmission couldn't be taken under control and spread rapidly all over the world. Many governments had to make rigid decisions to avoid the virus. It was announced that a quarantine period must begin from 12 March 2020 in our country. People were restricted for going outside, being in covered areas, being so closed to each other. Council of Higher Education announced that all institutions and universities will be closed after the date of 16 March 2020 according to governmental recommendations. Most universities had to continue their education by means of online education modules.

During the pandemic period the dentists were classified in the very-high-risk category due to the potential of exposure to coronavirus through aerosol-containing procedures by Occupational Safety and Health Administration (4,5). Dental institutions concerned great safety risks both for patients and students. Dental schools and hospitals accepted only emergency situations and were mostly closed according to recommendations of Ministry of Health and Council of Higher Education. Dental students turned their home and had to continue distance learning. Academic stuff met with a new 'online' curriculum; delivered virtual lectures on filesharing platforms. While preclinical simulation procedures proceeded by demonstration videos on the platforms clinical lessons interrupted. Didactic lessons and preclinical 
laboratories' lessons were mostly easy to survive online. Clinical training tried to proceed with case discussions.

Although face-to face education seems to be most effective and acceptable education style by authorities, distance learning was found to be successful in many studies. Online education is an education style that saves time and money, lets students to learn in their own way (6). Didactic lessons constitute the best choice for distance learning. It is easy to teach\& learn and effective (7). Distance learning is not a system that commonly used in health-related institutions in Turkey. In dental education, the students get clinical - based education as well as didactic education. It is a big challenge to train online clinical-based lessons. It is still unknown how to continue clinical-based lessons and clinical practice during or after pandemic period. According to the commentary results of a survey that The Association of Dental Education in Europe (ADEE) carried out, the long-term impact on clinical dental education is unclear (8). Meanwhile, the combination of online and face-to-face education 'blended learning' become more popular in dental education (9).

In this study, it was aimed to evaluate the effectiveness of online lessons and satisfaction of the students about distance learning.

\section{MATERIAL AND METHODS}

Ethical approval was obtained by the Non-Interventional Medicine Ethics Committee of Uşak University Faculty of Medicine on 23.09.2020 (Reference number: 76-08-04). After the pandemic period, all courses had to continue online. Theorical courses were given live and demo videos were filmed for practical courses. Case discussions which evaluating radiological images and clinical photos were done in clinical courses. All online videos were recorded and saved in Google Classroom Platform so students could watch again anytime they want.

This was a cross-sectional descriptive study that included dentistry students as the participants. 42-items questionnaire was conducted to dental students in Uşak University including age, gender, grade, nationality, usage of internet, thoughts and opinions about distance learning and the effect of distance learning to their education performance. The questionnaire consisted simple single answer and multiplechoice questions to determine the quality of current nonclinical and clinical education and to form a guide for future online dental education. Seven questions were aimed to gather information related to demographic data. Thirtytwo Lickert questions and 3 multiple choice questions were prepared on Google Forms and sent to students via school e-mail. It was planned to reach all 316 students who were registered to our faculty in 1 to 4 grades. All these students were attended both face-to-face courses and online courses in same year. The questionnaire was filled out anonymously.

\subsection{Statistical Analyses}

The data obtained through the questionnaire used as a data collection tool analyzed by quantitative methods by using the statistical analysis program of SPSS version 22.0 (IBM, Armonk, NY, USA). Exploratory factor analysis was performed. According to Kolmogorov-Smirnov test for normality of the distribution of variables; Kruskal-Wallis, Mann-Whitney $U$, and Spearman correlation test were used. Also, descriptive statistics were calculated and for categorical variables chisquare test was used.

\section{RESULTS}

Cronbach Alfa value for the questionnaire was 0.964. A total of 316 students were participated in this study and 302 of them completed the questionnaire. The response rate was $95.56 \%$. The percent of female students was $57.6 \%$ and male students was $42.4 \%$. The average age was $21 \pm 1.5$ and ranged from 18 to 29. Descriptive statistics were shown in Table 1. All of the students' responses to the questions were presented in Table 2. The detailed results of crucial questions were shown in Figure 1.

Table 1. Descriptive Statistics of the Present Study

\begin{tabular}{|c|c|c|}
\hline \multicolumn{2}{|l|}{ Variables } & \multirow{2}{*}{$\begin{array}{l}\text { Frequency (n) \% } \\
128(42.4 \%)\end{array}$} \\
\hline Gender & Male & \\
\hline & Female & $174(57.6 \%)$ \\
\hline \multirow[t]{4}{*}{ Grade } & First & $92(30.5 \%)$ \\
\hline & Second & $84(27.8 \%)$ \\
\hline & Third & $73(24.2 \%)$ \\
\hline & Fourth & $53(17.5 \%)$ \\
\hline \multirow[t]{2}{*}{ Nationality } & Turkish students & 291 (96.4\%) \\
\hline & Foreign students & $11(3.6 \%)$ \\
\hline \multirow[t]{3}{*}{ Region } & Village & $22(7.3 \%)$ \\
\hline & Town & $83(27.5 \%)$ \\
\hline & City & $197(65.2 \%)$ \\
\hline
\end{tabular}

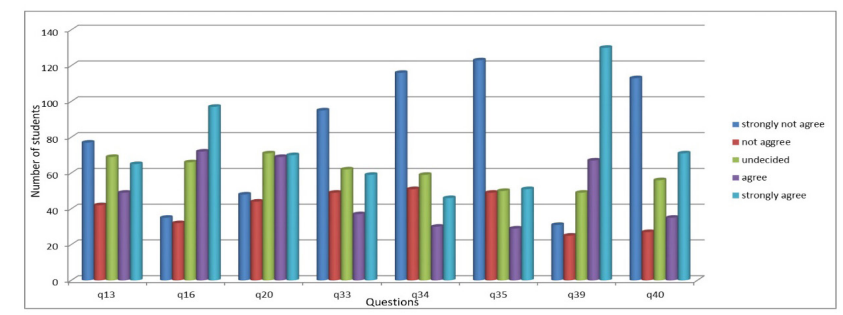

Figure 1. Graphical Representation of Crucial Questions Via Lickert Scale

Factor analysis was performed to check the suitability of the data. The Kaiser-Meyer-Olkin measure of sampling adequacy was 0.961 and Barlett's test of sphericity was significant $(p<0.001)$. According to rotation method (Oblimin with Kaiser Normalization) and the extraction method four factors were extracted. Only 1 item (Q27) had a value below than 0.30 so it wasn't related any factor and it was removed from the questionnaire. These four factors explained the $71.436 \%$ of variability and categorized as satisfaction, utilization, benefits of face-to-face, and handicap of face-to-face learning (Table 3). 
Table 2. Students Response to the Questionnaire

\begin{tabular}{|c|c|c|c|c|c|}
\hline Questions & $\begin{array}{l}\text { strongly } \\
\text { disagree }\end{array}$ & disagree & undecided & agree & $\begin{array}{l}\text { strongly } \\
\text { agree }\end{array}$ \\
\hline Q9.I have daily internet access & $11(3.6 \%)$ & $23(7.6 \%)$ & $53(17.5 \%)$ & $86(28.5 \%)$ & $129(42.7 \%)$ \\
\hline Q10. I know how to open. change. and upload online docs & $10(3.3 \%)$ & $29(9.6 \%)$ & $48(15.9 \%)$ & $104(34.4 \%)$ & $111(36.8 \%)$ \\
\hline $\begin{array}{l}\text { Q11. I access the internet daily or weekly to check course announcements } \\
\text { and online classes }\end{array}$ & $9(3.0 \%)$ & $28(9.3 \%)$ & $41(13.6 \%)$ & $86(28.5 \%)$ & $138(45.7 \%)$ \\
\hline Q12. I feel comfortable exploring / finding online lessons & $27(8.9 \%)$ & $21(7.0 \%)$ & $55(18.2 \%)$ & $77(25.5 \%)$ & $122(40.4 \%)$ \\
\hline Q13. I am satisfied with distance education & $77(25.5 \%)$ & $42(13.9 \%)$ & $69(22.8 \%)$ & $49(16.2 \%)$ & $65(21.5 \%)$ \\
\hline Q14. I liked the distance education & $84(27.8 \%)$ & $43(14.2 \%)$ & $62(20.5 \%)$ & $46(15.2 \%)$ & $67(22.2 \%)$ \\
\hline Q15. I am enthusiastic to attend distance learning courses & $79(26.2 \%)$ & $45(14.9 \%)$ & $68(22.5 \%)$ & $43(14.2 \%)$ & $67(22.2 \%)$ \\
\hline Q16. I followed the lessons regularly & $35(11.6 \%)$ & $32(10.6 \%)$ & $66(21.9 \%)$ & $72(23.8 \%)$ & $97(32.1 \%)$ \\
\hline Q17. I followed online classes more than traditional/face-to-face training & $119(39.4 \%)$ & $45(14.9 \%)$ & $44(14.6 \%)$ & $41(13.6 \%)$ & $53(17.5 \%)$ \\
\hline Q18. I had no problem logging into the system and following the lessons & $35(11.6 \%)$ & $41(13.6 \%)$ & $47(15.6 \%)$ & $82(27.2 \%)$ & $87(32.1 \%)$ \\
\hline Q19. I was able to solve the problems that I had while logging into the system & $14(\% 4.6)$ & $22(7.3 \%)$ & $63(20.9 \%)$ & $101(33.4 \%)$ & $102(33.8 \%)$ \\
\hline Q20. I was able to understand the subjects taught by distance education & $48(15.9 \%)$ & $44(14.6 \%)$ & $71(23.5 \%)$ & $69(22.8 \%)$ & $70(23.2 \%)$ \\
\hline Q21. Where I didn't understand I was able to consult the instructor & $28(9.3 \%)$ & $35(11.6 \%)$ & $75(24.8 \%)$ & $73(24.2 \%)$ & $91(30.1 \%)$ \\
\hline $\begin{array}{l}\text { Q22. I felt more comfortable participating actively in online classes } \\
\text { than face-to-face training. }\end{array}$ & $84(27.8 \%)$ & $45(14.9 \%)$ & $48(15.9 \%)$ & $59(19.5 \%)$ & $66(21.9 \%)$ \\
\hline Q23. I could understand the demonstrations shown by videos in distance education & $62(20.5 \%)$ & $47(15.6 \%)$ & $61(20.2 \%)$ & $65(21.5 \%)$ & $67(22.2 \%)$ \\
\hline Q24. Online lessons helped me learn & $43(14.2 \%)$ & $40(13.2 \%)$ & $79(26.2 \%)$ & $68(22.5 \%)$ & $72(23.8 \%)$ \\
\hline Q25. The videos helped me learn & $37(12.3 \%)$ & $41(13.6 \%)$ & $71(23.5 \%)$ & $70(23.2 \%)$ & $83(27.5 \%)$ \\
\hline $\begin{array}{l}\text { Q26. Distance learning has been useful in communicating and interacting } \\
\text { with instructors and other students }\end{array}$ & 45 (14.9\%) & $58(19.2 \%)$ & $67(22.2 \%)$ & $55(18.2 \%)$ & $77(25.5 \%)$ \\
\hline Q28. I like being able to access distance education at any time & $21(7.0 \%)$ & $14(4.6 \%)$ & $30(9.9 \%)$ & $68(22.5 \%)$ & $169(56 \%)$ \\
\hline Q29. I like being able to access distance education from anywhere & $22(7.3 \%)$ & $15(5.0 \%)$ & $34(11.3 \%)$ & $70(23.2 \%)$ & $161(53.3 \%)$ \\
\hline Q30. I am glad to be able to study from anywhere in the world & $23(7.6 \%)$ & $17(5.6 \%)$ & $47(15.6 \%)$ & $73(24.2 \%)$ & $142(47 \%)$ \\
\hline $\begin{array}{l}\text { Q31. I like how distance education gives students the power to manage their } \\
\text { education }\end{array}$ & $40(13.2 \%)$ & $31(10.3 \%)$ & $47(15.6 \%)$ & $71(23.5 \%)$ & $113(37.4 \%)$ \\
\hline Q32. I like that distance education is at my pace/control & $32(10.6 \%)$ & $29(9.6 \%)$ & $48(15.9 \%)$ & $72(23.8 \%)$ & $121(40.1 \%)$ \\
\hline Q33. I believe that I will be successful as a result of distance education & $95(31.5 \%)$ & $49(16.2 \%)$ & $62(20.5 \%)$ & $37(12.3 \%)$ & $59(19.5 \%)$ \\
\hline $\begin{array}{l}\text { Q34. I think distance education is more beneficial than traditional } \\
\text { face-to-face education }\end{array}$ & $116(38.4 \%)$ & $51(16.9 \%)$ & $59(19.5 \%)$ & $30(9.9 \%)$ & $46(15.2 \%)$ \\
\hline $\begin{array}{l}\text { Q35. I think videos shown in distance education are more useful than live } \\
\text { demonstrations }\end{array}$ & $123(40.7 \%)$ & $49(16.2 \%)$ & $50(16.6 \%)$ & $29(9.6 \%)$ & $51(16.9 \%)$ \\
\hline $\begin{array}{l}\text { Q36. I think it is a disadvantage that distance education requires a computer and the } \\
\text { internet }\end{array}$ & $39(12.9 \%)$ & $36(11.9 \%)$ & $55(18.2 \%)$ & $57(18.9 \%)$ & $115(38.1 \%)$ \\
\hline Q37. Online lectures should replace traditional lectures and live demonstrations & $114(37.7 \%)$ & $54(17.9 \%)$ & $63(20.9 \%)$ & $26(8.6 \%)$ & $45(14.9 \%)$ \\
\hline $\begin{array}{l}\text { Q38. Online courses and tutorials need to be further developed to support my } \\
\text { learning }\end{array}$ & $16(5.3 \%)$ & $12(4.0 \%)$ & $67(22.2 \%)$ & $96(31.8 \%)$ & $111(36.8 \%)$ \\
\hline Q39. I prefer the combination of traditional education and online classes & $31(10.3 \%)$ & $25(8.3 \%)$ & $49(16.2 \%)$ & $67(22.2 \%)$ & $130(43.0 \%)$ \\
\hline Q40. I would like the distance education to continue in the new academic year & $113(37.4 \%)$ & $27(8.9 \%)$ & $56(18.5 \%)$ & $35(11.6 \%)$ & $71(23.5 \%)$ \\
\hline
\end{tabular}


Table 3. Factor Analyses of the Questionnaire

\begin{tabular}{|c|c|c|c|c|}
\hline \multirow[t]{2}{*}{ Questions } & \multicolumn{4}{|c|}{ Components } \\
\hline & 1 & 2 & 3 & 4 \\
\hline Q9 & & .909 & & \\
\hline Q10 & & .778 & & \\
\hline Q11 & & .875 & & \\
\hline Q12 & & .851 & & \\
\hline Q13 & .708 & & & \\
\hline Q14 & .763 & & & \\
\hline Q15 & .710 & & & \\
\hline Q16 & .474 & & & \\
\hline Q17 & .790 & & & \\
\hline Q18 & & .574 & & \\
\hline Q19 & & .705 & & \\
\hline Q20 & .644 & & & \\
\hline Q21 & .339 & & & \\
\hline Q22 & .630 & & & \\
\hline Q23 & .700 & & & \\
\hline Q24 & .612 & & & \\
\hline Q25 & .580 & & & \\
\hline Q26 & .684 & & & \\
\hline \multicolumn{5}{|l|}{ Q27 } \\
\hline Q28 & & & .936 & \\
\hline Q29 & & & .905 & \\
\hline Q30 & & & .788 & \\
\hline Q31 & & & .657 & \\
\hline Q32 & & & .714 & \\
\hline Q33 & .846 & & & \\
\hline Q34 & .986 & & & \\
\hline Q35 & .937 & & & \\
\hline Q36 & & & & .594 \\
\hline Q37 & .997 & & & \\
\hline Q38 & & & & .808 \\
\hline Q39 & & & & .537 \\
\hline Q40 & .845 & & & \\
\hline
\end{tabular}

Male students more pleased than female students in term of distance learning $(p=0.032)$. They felt more enthusiastic to attend online lessons than females $(p=0.019)$. Fourth grade students were significantly pleased distance learning than first and second grade students according to the satisfaction questions $(p<0.05)$. There was no significant difference among grades according to the utilization questions ( $p>0.05)$. There were 5 questions about benefits of face-face learning and first grade students were significantly pleased with only Q31 than fourth grade's ( $p=0.004)$. There was no significant difference among grades according to the handicap of distance learning questions ( $p>0.05$ ). There was a positive correlation between grades and Q34, Q37, and Q40 $(p<0.05)$ (Table 4).

Foreign students agreed (54.5\% strongly agree and $9.1 \%$ agree) that they could understand the subjects with online lessons and could consult with the professor $(36.4 \%$ strongly agree and $36.4 \%$ agree). Besides, they agreed ( $45.5 \%$ strongly agree and $18.2 \%$ agree) that they felt more comfortable participating actively in online lessons than face-to-face $(p=0.047)$. Finally, they were glad to study from anywhere in the world $(72.7 \%$ strongly agree and $9.1 \%$ agree).

The students who used computer, followed the lessons regularly and had less problem in joining/following the online lessons, significantly $(p<0.05)$. According to the responses about internet usage (Q6, Q7, Q9, Q10, Q11, Q12, Q36), it had found that students lived in village had trouble using internet, significantly $(p<0.05)$ Thus they followed lessons via mobile phone $(p=0.014)$.

The reason of using internet mostly for checking on social media (78.8\%). While $63.9 \%$ of students were listening music/watching videos on internet, only $25.8 \%$ of them were trying to reach web-based training programs. Their opinions about difficulties of quarantine period and distance learning were asked in multiple choice questions and the percentages of responses were given in Figure 2.

Table 4. P Values of Comparison of the Grades According to 'Satisfaction' Component

\begin{tabular}{|l|l|l|l|l|l|l|l|l|l|l|l|l|l|l|l|l|l|l|}
\hline & Q13 & Q14 & Q15 & Q16 & Q17 & Q20 & Q21 & Q22 & Q23 & Q24 & Q26 & Q33 & Q34 & Q35 & Q37 & Q40 \\
\hline $\mathbf{1 - 2}$ & 1.000 & 1.000 & 1.000 & 1.000 & 1.000 & 1.000 & 0.505 & 1.000 & 1.000 & 1.000 & 1.000 & 1.000 & 1.000 & 1.000 & 1.000 & 1.000 \\
\hline $\mathbf{1 - 3}$ & 1.000 & 0.745 & 1.000 & 0.052 & 0.189 & 1.000 & 0.219 & 0.368 & 1.000 & 1.000 & 0.750 & 1.000 & 1.000 & 1.000 & 1.000 & 1.000 \\
\hline $\mathbf{1 - 4}$ & 0.004 & 0.000 & 0.004 & 0.006 & 0.000 & 0.004 & 0.020 & 0.001 & 0.007 & 0.008 & 0.019 & 0.000 & 0.000 & 0.164 & 0.007 & 0.034 \\
\hline $\mathbf{2 - 3}$ & 1.000 & 1.000 & 1.000 & 0.129 & 1.000 & 1.000 & 1.000 & 1.000 & 1.000 & 1.000 & 1.000 & 1.000 & 1.000 & 1.000 & 1.000 & 0.948 \\
\hline $\mathbf{2 - 4}$ & 0.008 & 0.002 & 0.042 & 0.016 & 0.000 & 0.005 & 1.000 & 0.055 & 0.013 & 0.008 & 0.046 & 1.000 & 0.001 & 0.032 & 0.045 & 0.002 \\
\hline $\mathbf{3 - 4}$ & 0.062 & 0.040 & 0.203 & 1.000 & 0.014 & 0.095 & 1.000 & 0.294 & 0.281 & 0.307 & 0.826 & 0.016 & 0.026 & 0.166 & 0.191 & 0.153 \\
\hline
\end{tabular}




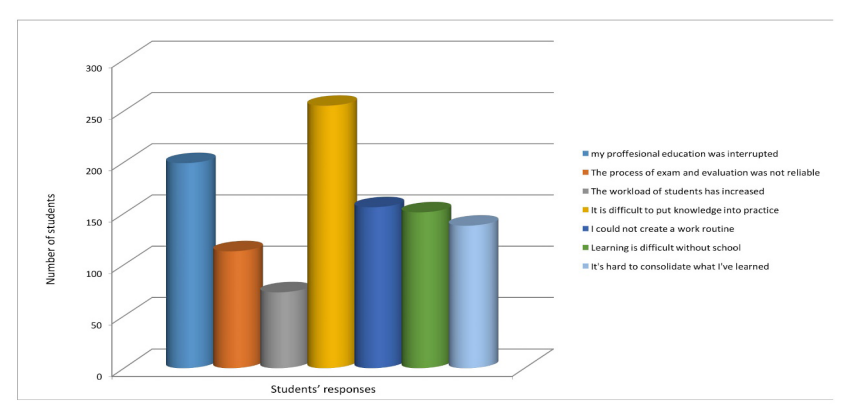

Figure 2. The Responses to the Multiple-Choice Questions Choice Questions

\section{DISCUSSION}

As we all know COVID-19 pandemic affects everyone and everything negatively. Our usual life stopped and everyone had to change daily routines. Institutions also had to change their routine education systems. Online education, distance learning became our new normal. The faculties based on practical training like dental schools were curious about online education all over the world, is it enough or not. Dental students were also curious and stressed. Therefore, our main aim was to evaluate the satisfaction of the students about distance learning in this study.

While online education was popular in some studies, (1012) the students' opinions were not clear about if they were pleased about distance learning in this study. While $39.4 \%$ of them were not agreed, $37.7 \%$ of them were agreed. When we evaluate according to the grades, it was found that $4^{\text {th }}$ grade students were more pleased. In our faculty, clinical training begins at the $2^{\text {nd }}$ semester of $3^{\text {rd }}$ grade. So $4^{\text {th }}$ grade students had a clinical experience when quarantine begins. They also have baseline training about didactic lessons. It can be thought that it was easier to intensify the courses than building a new knowledge like in $1^{\text {st }}$ grade. Also, online case discussions were able to affect positively reinforcing courses in $4^{\text {th }}$ grade. $1^{\text {st }}$ grade student who were building a new knowledge about dentistry, were the most unpleased students. They had difficulties in learning without a strong base.

While many studies stated no difference according to gender, contrary to Mubayrik et al (13) study we found that male students were more pleased with online lessons than female students $(11,14)$. It was attributed to that they were more enthusiastic to attend online lessons significantly. It could be related to the socio-cultural difference between countries.

Results of present study indicated that students lived in village had trouble using internet and preferred to follow lessons via mobile phone. The percent of students that followed online lessons regularly was low (18.2\% for strongly agree and $13.6 \%$ for agree) among the students living in village. Speed and quality of internet connection may be affected by location and it decreases in rural area. Decreasing of speed and quality of internet connection might be reason of choosing mobile phone against computer.

Online education has some disadvantages like requiring computer and internet that most of the students agreed. This could affects joining and following the lessons. Most of the students could follow the lessons regularly. Besides the students who joined the lessons via computer were significantly more comfortable following the lessons regularly. It could be related to sitting in front of computer at a table makes mind more open than watching tablet or mobile phone in a relax mode. Internet is one of the biggest dilemma for this century. It is very useful and dangerous at the same time. When the students were asked the purpose of using internet, $78.8 \%$ of the answers were pointing out social media. They spent a lot of time on social media instead of web-based training programs. Social media usage was extremely higher in the current study than the study of Roberts et al (15) (52\%); probably by means of the quarantine days' vapidity.

Foreign students felt more comfortable participating actively in online lessons than face-to-face. It could be explained that they could contributed and consulted freely by writing

their opinions. However, they did not believe that they could be successful at the end of education like Turkish students. They may have thought that clinic education would not be beneficial enough for them to be carried out online. Besides, the fact that Turkish is not their native language is also a handicap for them.

There are many studies having different results in dental education about blended learning $(6,10-12,14,16-18)$. Especially it became a requirement during the pandemic period. Liu et al (19) declared that online dental continuing education increased when COVID-19 was just an epidemic in China.

Distance learning was found to be more useful in previous studies (10-12). Smith et al (10) reported that video-clips were preferred more than preclinical demonstrations for tooth preparations by students. However, students agreed that it would be better if the supervisor cares individually for improving their skills than watching video clips.

The studies comparing education systems found that blended learning was mostly chosen by the students $(6,11,14,16-18)$. Asiry et al (6) investigated the dental students' perceptions of an online learning and they reported that most of the students preferred a combination of face-to-face learning and online learning. According to the results of Pahinis et al (14) study, students felt comfortable with face-to-face and online-supported learning. Bains et al (18) conducted a study which evaluated the effectiveness of face-to-face, blended, and e-learning for the cephalometric education. They reported that blended learning was the most accepted learning type by the students. The students didn't show much confidence on they would be successful in our study. Most of the students thought that distance learning was not better than face-to-face learning and mostly they were not so closed to continue online lessons next year. They had great 
hesitations about their profession, mostly for clinical training like in a Brazilian study (20). It was also commented on the study of Bennardo et al (21) as the clinical training can not be digitalized totally. The students would rather combination of face-to-face lessons and online lessons in accordance with previous studies. It can be related to the nature of dentistry education. Didactic lessons and clinical training combine a successful education. Without practicing on patients, the students can not have self-confidence. It was proved by the response to the multiple-choice questions about their opinions. $84.4 \%$ of the students declared that it is difficult to put into practice that has been learned and $65.9 \%$ of them thought that their professional education was interrupted.

This study is one of the few studies in which dental education was evaluated by students during the COVID-19 pandemic in Turkey and it showed that the opinion of professors that it would not be very appropriate to conduct clinical and practical training in dentistry with a distance education model was similar among students. The appropriate education model has been discussed and it is thought that it will shed light on further studies.

There was some limitation in this study. A new survey form was created by examining the survey questions in similar studies and the survey evaluated the students' perspective about the success of distance learning not the real success. In addition, the data were obtained from the students of a single dentistry school, so just one dentistry school education was evaluated in this study.

\section{CONCLUSION}

COVID-19 pandemic seems to have an influence on dentistry education. Besides online training programmes, education systems begin to change. While dentistry schools having problems with continuing face-to-face education system, they need to move on clinical work within new COVID-19 protocols. It can be thought that blended learning begins to rise as all dental schools' new approach.

Within the limitations of this study; dental students are not so satisfied about online education. They have some hesitations especially on clinical performance. They don't have much self-confidence to face with patients via online training. Only $4^{\text {th }}$ grade students who treated patients before pandemic period think optimistic about distance learning. Most of the students agree that blended education is a good choice.

It can be concluded that blended education will be a good alternative system for future dental education. Further studies are needed to evaluate more data around the world to improve dental education system after COVID-19 pandemic, before other pandemics.

\section{Funding: None}

Conflict of interest statement: All authors state that they have no conflict of interest

\section{REFERENCES}

[1] Guan W, Ni Z, Hu Y, Hu Y, Liang W, Ou C, He J, Liu L, Shan H, Lei C, Hui D, Du B, Li L, Zeng G, Yuen K, Chen R, Tang C, Wang T, Chen P, Xiang J, Li S, Wang J, Liang Z, Peng Y, Liu Y, Hu Y, Peng P, Wang J, Liu J, Chen Z, Li̇ G, Zheng Z, Qui S, Luo J, Ye C, Zhu $\mathrm{S}$, and Zhong N. Clinical characteristics of coronavirus disease 2019 in China. N Engl J Med. 2020;382(18):1708-1720.

[2] Zhu N, Zhang D, Wang W, Li X, Yang B, Song J, Zhao X, Huang B, Shi W, Lu R, Niu P, Zhan F, ma X, Wang D, Xu W, Wu G, Gao G, and Tan W. A novel coronavirus from patients with pneumonia in China, 2019. N Engl J Med. 2020;382(8): 727-733.

[3] WHO. OMS definition. WHO Director-General's remarks at the media briefing on 2019-nCoV on 11 March 2020. Available from: URL:https://www.who.int/dg/speeches/detail/whodirector-general-s-opening-remarks-at-the-media-briefingon-COVID-19 11 March, 2020

[4] OSHA. OSHA guidance summary: Preparing workplaces for COVID-19. Available from: https://www.osha.gov/sites/ default/files/publications/OSHA3990.pdf-2020

[5] Educational Debt. American Dental Education A. Available from: URL:https://www.adea.org/GoDental/Money_Matters/ Educational_Debt.aspx. April 18, 2020

[6] Asiry MA. Dental students' perceptions of an online learning. Saudi Dent J. 2017;29(4):167-10.

[7] Gianoni-Capenakas S, Lagravere M, Pacheco-Pereira C, Yacyshyn J. Effectiveness and perceptions of flipped learning model in dental education: A systematic review. J Dent Educ. 2019;83(8): 935-945.

[8] Quinn B, Field J, Gorter R, Akota I, Paganelli M, Davies J, Dixon J. COVID-19: The immediate response of european academic dental institutions and future implications for dental education. Eur J Dent Educ. doi:10.1111/eje.12542. [Epub ahead of print].

[9] Qutieshat A, Abusamak M, Maragha T. Impact of blended learning on dental students' performance and satisfaction in clinical education. J Dent Educ. 2020;84(2):135-142.

[10] Smith W, Rafeek R, Marchan S, Paryag A. The use of video-clips as a teaching aide. Eur J Dent Educ. 2012;16(2):91-6.

[11] Turkyilmaz I, Hariri NH, Jahangiri L. Student's perception of the impact of E-learning on dental education. J Contemp Dent Pract. 2019;20(5):616-621.

[12] Pilcher ES. Students' evaluation of online course materials in fixed prosthodontics: A case study. Eur J Dent Educ. 2001;5(2):53-9.

[13] Bin Mubayrik HF. Exploring adult learners' viewpoints and motivation regarding distance learning in medical education. Adv Med Educ Pract. 2020;11:139-146.

[14] Pahinis K, Stokes CW, Walsh TF, Cannavina G. Evaluating a blended-learning course taught to different groups of learners in a dental school. J Dent Educ. 2007;71(2):269-78.

[15] Roberts BS, Roberts EP, Reynolds S, Stein AF. Dental students' use of student-managed google docs and other technologies in collaborative learning. J Dent Educ. 2019;83(4):437-444.

[16] Naser-ud-Din S. Introducing scenario based learning interactive to postgraduates in orthodontic program. Eur J Dent Educ. 2015;19(3):169-76.

[17] McCann AL, Schneiderman ED, Hinton RJ. E-teaching and learning preferences of dental and dental hygiene students. J Dent Educ. 2010;74(1):65-78. 
[18] Bains M, Reynolds PA, Mcdonald F, Sherriff M. Effectiveness and acceptability of face-to-face, blended and e-learning: A randomised trial of orthodontic undergraduates. Eur J Dent Educ. 2011;15(2):110-7.

[19] Liu X, Zhou J, Chen L, Yang Y, Tan J. Impact of COVID-19 epidemic on live online dental continuing education. Eur J Dent Educ 2020;24(4):786-789.
[20] Peloso RM, Ferruzzi F, Mori AA, Camacho D, Franzin L, Teston $A$, and Freitas K. Notes from the field: Concerns of healthrelated higher education students in brazil pertaining to distance learning during the coronavirus pandemic. Eval Heal Prof 2020;43(3):201-203.

[21] Bennardo F, Buffone C, Fortunato L, Giudice A. COVID-19 is a challenge for dental education-A commentary. Eur J Dent Educ 2020 [Epub ahead of print]. doi:10.1111/eje.12555

How to cite this article: Ezberci S, Yildrim B. Evaluation of the Effectiveness of Distance Learning in Dental Education During COVID-19 Pandemic in Turkey. Clin Exp Health Sci 2021; 11: 630-636. DOI: 10.33808/ clinexphealthsci.913386 